\title{
A TECHNOLÓGIAI HALADÁS INTÉZMÉNYI VONATKOZÁSAI
}

\section{THE INSTITUTIONAL ASPECTS OF TECHNOLOGICAL PROGRESS}

\author{
Csugány Julianna \\ PhD, adjunktus \\ Eszterházy Károly Egyetem, Gazdaság- és Társadalomtudományi Kar Gazdaságtudományi Intézet Közgazdaságtan Tanszék \\ csugany.julianna@uni-eszterhazy.hu
}

\begin{abstract}
ÖSSZEFOGLALÁS
A gazdasági növekedés hajtóerejének tekintett technológiai haladás vizsgálatában egyre nagyobb hangsúlyt fektetnek az intézményi tényezőkre. Douglass North mutatott rá arra, hogy a világ nagy részén nem érvényesülnek a technológia lehetséges előnyei, vagyis valami még kell ahhoz, hogy növekedést generáljon. A technológiai fejlődésben nem csupán a tudás, valamint a tudományos eredmények és azok gyakorlati alkalmazása fontos, hanem az az intézményi környezet is, amelyben ezek az újdonságok megszületnek. Az intézmények ösztönzőket teremtenek az újításhoz a gazdasági szereplők számára, melyek különbözősége magyarázatot adhat az országok között kialakult technológiai rés, valamint jövedelemegyenlőtlenségek okaira. A technológiai fejlődésben élen járó országok intézményi környezete eltérő, nincs tehát egyenrecept a haladásnak kedvező, megfelelő intézményi struktúra kialakításához. Az első ipari forradalom élenjárója a jellemzően piacbarát Nagy-Britannia, valamint Európa északi, aktív állami szerepvállalással jellemezhető skandináv jóléti államai eltérő fejlődési pályát jártak be a kimagasló innovációs teljesítményük eléréséhez. Jelen tanulmány a technológiai haladás szempontjából releváns intézményi összefüggéseket mutatja be a technológia, az intézmények és a gazdasági növekedés kontextusában.
\end{abstract}

\begin{abstract}
Institutional factors are more and more important in analysis of technological progress which is the driving force of economic growth. Douglass North pointed out that the potential benefits of technology do not prevail much of the world, so something else is also needed to realise growth. In technological progress, not only knowledge and scientific results are important, but also the institutional environment where these innovations are born. Institutions create incentives to economic actors, its differences can explain the technological gap between countries and reasons of income inequalities. In leading countries of innovation the institutional environment is different so there is no recipe how to create appropriate institutional structure. Great Britain, the pioneer of the first industrial revolution, is market-friendly, while the Scandinavian countries are characterized by active state intervention. The institutions concerned are different but their performance in innovation is respectively dominant. This paper presents the technological progress in terms of relevant institutional relationships in the context of technology, institutions and economic growth.
\end{abstract}


Kulcsszavak: technológiai fejlődés, intézményi környezet, formális és informális szabályok, gazdasági és politikai intézmények, tulajdonjogi biztonság

Keywords: technological progress, institutional environment, formal and informal rules, economic and political institutions, protection of property rights

\section{BEVEZETÉS}

„A technológia kudarca gyakran az intézmények kudarca" Mokyr $(2003,60$.

A technológiai fejlödés egy olyan dinamikus folyamat, amely az új technológia létrehozásától, illetve átvételétől a termelékenységben is érezhető javulás realizálódásával válik a gazdasági növekedés motorjává. A folyamat komplexitása okán valamennyi szakaszban megjelennek az intézmények, melyek hatással vannak az újitáshoz kapcsolódó döntések meghozatalára, az új technológia alkalmazásának időzítésére, és a terjedés lehetőségeire is. A formális szabályokat és informális kötöttségeket magában foglaló intézményi környezet nemcsak a gazdasági müködés feltételrendszerét teremti meg, hanem meghatározza a fejlődési lehetőségeket is.

A technológiai haladás és a gazdasági növekedés kapcsolatrendszerének modellezésében Robert Solow (1956) elmélete mérföldkőnek számít, mely szerint hosszú távon gazdasági növekedés csak a teljes tényezötermelékenység növekedésében megnyilvánuló technológiai haladás révén érhető el. A modellben a technológia tökéletes közjószág, mely mindenki számára szabadon elérhető és felhasználható, a modell szempontjából exogén. Az új növekedéselméleti irányzat képviselői azonban már endogén tényezőként, a többi gazdasági változóval összefüggően modellezik, s implicit módon feltételezik az intézmények létét, amelyek biztosítják az innováció megvalósulását és a humán tőke felhalmozását (Czeglédi, 2004).

Az intézményi környezet a technológiai haladás folyamatában azért fontos, mert ösztönzőket teremt a gazdaság szereplőinek az újításhoz. Ennek köszönhetően a növekedéselmélet mellett az intézményrendszer kialakulását és müködését tanulmányozó intézményi közgazdaságtan is egyre fokozottabb érdeklődést mutat az intézmények növekedésben, valamint a technológiai fejlödésben betöltött szerepe iránt. A technológiai haladás lényegében a technológia és az intézmények sajátos ötvözetében valósul meg, s járul hozzá a gazdasági növekedéshez, mely szintén visszahat a technológiai fejlődésre. Ezt az összefüggésrendszert szemlélteti az 1. ábra.

Az intézmények, melyeket northi értelemben véve egyszerúen játékszabályként értelmezhetünk, számos formában jelennek meg a gazdaságban, és összetett hatásmechanizmuson keresztül határozzák meg a gazdasági müködés feltétel- 


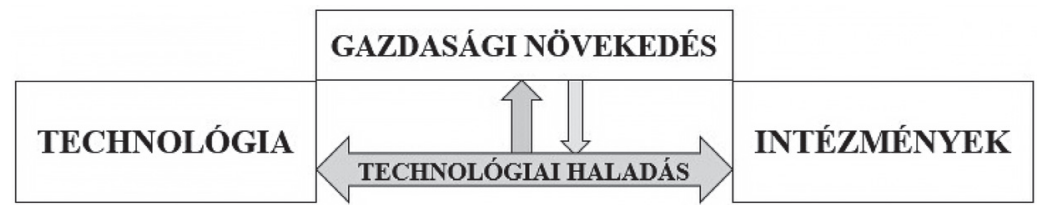

1. ábra. A technológia, az intézmények és a gazdasági növekedés összefüggésrendszere (saját konstrukció)

rendszerét. De mely intézmények és hogyan képesek befolyásolni a technológiai fejlödés folyamatát? E kérdés megválaszolása számos kutatást indukál, mind az intézményi közgazdaságtan, mind a növekedéselmélet területén. Jelen tanulmány a technológiai fejlődés intézményi aspektusairól kíván átfogó képet nyújtani.

\section{AZ INTÉZMÉNYEK SZÁMÍTANAK...}

Az országok között a gazdasági növekedés tekintetében megfigyelhető különbségek kapcsán Joel Mokyr (2003) a tőkefelhalmozás és a technológiai fejlődés mellett az intézményi sajátosságok jelentőségét is kiemeli. A schumpeteri növekedés alapja a technológia, az új tudás létrehozása, míg a northi növekedést az intézményi változás indukálja, ugyanis a piac tökéletlenségéből fakadó költségeket és kockázatokat kiszámíthatóságuknak köszönhetően az intézmények csökkentik. A tranzakciós költségek mérséklésével az intézmények hatékonyabb erőforrás-allokációt tesznek lehetővé, így érhető el a termelékenység növekedése. A gazdasági növekedés magyarázatában tehát a technológiai fejlődés és az intézmények egyaránt meghatározóak. Az országok közötti technológiai rés magyarázatában kiemelt szerepet kap a technológia és az intézmények sajátos kölcsönhatása.

Az országok hosszú távú gazdasági teljesítményét Robert E. Hall és Charles I. Jones (1999) szerint elsődlegesen az egyének és a vállalatok számára ösztönzőket teremtő, intézményeket és kormányzati politikákat magában foglaló társadalmi infrastruktúra alapozza meg, olyan gazdasági környezetet teremtve, mely elősegíti a képességek, készségek, azaz a humán tőke, valamint a beruházásokon keresztül a fizikai tőke felhalmozását, továbbá az innovációt és a technológiatranszfert, melyek hozzájárulnak a kibocsátás növekedéséhez. A gazdasági intézmények nemcsak a tőkefelhalmozást ösztönzik, hanem a jobb technológia létrehozását, átvételét, alkalmazását is. Daron Acemoglu és szerzőtársai szerint (2005) az intézmények legfőbb feladata a tranzakciók lebonyolításához szükséges szerződéskötés megkönnyítése, a piacok müködésének és az erőforrások elosztásának hatékonyabbá tétele, valamint olyan környezet kialakítása, mely pozitívan hat a beruházási hajlandóságra. Az intézmények lassan változnak, ezáltal kiszá- 
míthatóságot biztosítanak a gazdaságban, melynek köszönhetően képesek az innováció melletti bizonytalanság csökkentésére is.

A technológiai változásokat intézményi átalakulások kísérik, az új technológia megjelenése és alkalmazása, a gazdasági-technológiai paradigmaváltás intézményi változásokat is generál. A technológiai és az intézményi változások kölcsönhatásának, valamint az intézmények gazdasági teljesítményre gyakorolt hatásának vizsgálatát Pavel Pelikan az evolúciós közgazdaságtan keretei közé illeszti. A technológia és az intézmények koevolúciós fejlődési modellje alapján az intézmények teremtik meg a technológiai változások lehetőségét, melyek abszorpciója azonban intézményi változásokat igényel (Pelikan, 2003). Az ipari forradalmak vizsgálata a technológiai és intézményi változások összefüggésénél azért releváns, mert minden korszakban a meghatározó technológia más-más intézményeket igényel, vagyis alkalmazkodni kell az adott kor kihívásaihoz. A technológiai változásokat a tudás gyakorlati alkalmazása generálja, amelyhez szükséges ismeretek és készségek megszerzésének irányát az intézményi keretek szabják meg (North, 1990, 78.). A tudomány és a technológia kölcsönösen hatnak egymásra, a technológiai fejlödés irányt mutat a tudományos kutatásoknak, a tudomány pedig megalapozza az új technológia létrehozását (Mokyr, 2003). Azok az országok sikeresebbek, amelyek olyan intézményi környezetet alakítottak ki, mely gyorsabban és jobban tud alkalmazkodni a változásokhoz. A megváltozott körülményekhez való folytonos alkalmazkodás a fenntartható intézményrendszer alapja, amely a gazdasági növekedés feltétele (Czeglédi, 2005).

\section{A TECHNOLÓGIAI HALADÁS AZ INTÉZMÉNYI KÖZGAZDASÁGTAN SZEMSZÖGÉBŐL}

A technológia alapvető szerepet játszik a hosszú távú gazdasági növekedés, illetve az országok közötti jövedelmi különbségek magyarázatában is. A technológiai és intézményi változások összefüggései alapján világossá válik, hogy az intézmények is fontosak az országok térben és időben eltérő gazdasági teljesítményének megértéséhez. Az intézményi tényezők különböző szempontok szerint csoportosíthatók, melyek alapján megállapítható, hogy eltérő módon járulnak hozzá a technológiai haladás realizálódásához.

Az új intézményi közgazdaságtan kiemelkedő képviselője, Douglass North szerint az intézmények az emberek által kialakított korlátok, amelyeket a közöttük kialakuló gazdasági, társadalmi és politikai interakciók szabályozására hoznak létre (North, 1990, 3.). Az intézmények northi értelmezésében vannak formális és informális, azaz írott és íratlan szabályok, ugyanakkor különbséget lehet tenni a társadalom játékszabályai, valamint a játékosok, azaz a szervezetek között. A technológiai fejlődés szempontjából a politikai, gazdasági és jogi szabályokat, valamint a szerződéseket magában foglaló formális korlátok közül elsősorban a 
törvények és tulajdonjogok lényegesek, míg az informális korlátozások, mint a normák és a viselkedési szabályok kiegészítik és növelni tudják a formális szabályok hatékonyságát (North, 1990, 46-47.). Egy új technológiában rejlő lehetőségek kiaknázásához intézményi változásokra is szükség van. Az informális intézményeken nehezebb változtatni, a társadalmi szerkezetátalakulás eredményezheti ezen korlátok megváltozását. A politikai rendszer könnyebben képes a formális szabályokat a megváltozott körülményekhez alakítani. Hatékonyan múködő piacon a szabályozás ösztönzi a tanulást, a tudás gyarapítását, ily módon innovációt indukál.

Richard R. Nelson (2002) az intézményeket társadalmi technológiaként definiálta, amely a szereplők között kialakuló interakciók és tranzakciók, valamint szokások és szabályok összessége, míg a fizikai technológia az a rutin, mellyel a gazdasági szereplők az inputokból outputot állítanak elő. Az új rutin megtanulása, azaz az új technológia megjelenése költséges és kockázatos, a gazdaságban történő alkalmazásával összefüggésben értékelődik fel a társadalmi technológia szerepe. A technológiai fejlődés a mokyri értelemben vett mikro- és makrotalálmányok jelentette fizikai technológia, valamint az intézményeket és a szervezeteket magában foglaló társadalmi technológia kölcsönhatásában nyilvánul meg (Kapás, 2007).

Az intézményi környezet összetettségében egyfajta rendszert teremt Óliver Williamson (2000), aki a társadalmi elemzés négy szintjét különbözteti meg, ahol minden szint korlátot jelent az alatta lévő számára. A struktúra mentén jól jellemezhetök a technológiai fejlődés intézményi vonatkozásai (1. táblázat).

1. táblázat. A technológiai fejlődés intézményi jellemzői a williamsoni struktúrában

\begin{tabular}{|c|c|c|}
\hline Szint & & A technológiai fejlődés intézményi jellemzői \\
\hline L1 & $\begin{array}{l}\text { Társadalmi beágyazottság } \\
\text { normák, szokások, tradíciók }\end{array}$ & $\begin{array}{l}\text { új, újítás iránti társadalmi attitủd, } \\
\text { innovációs hajlandóság, innovációs potenciál }\end{array}$ \\
\hline L2 & $\begin{array}{l}\text { Intézményi környezet } \\
\text { formális szabályok - } \\
\text { jogrendszer, törvények, } \\
\text { tulajdonjogok }\end{array}$ & $\begin{array}{l}\text { szellemi tulajdon védelme, } \\
\text { nemzeti innovációs rendszer, } \\
\text { innovációval kapcsolatos törvények, jogszabályok }\end{array}$ \\
\hline L3 & $\begin{array}{l}\text { Irányitási formák } \\
\text { kormányzat }\end{array}$ & $\begin{array}{l}\text { új termékhez, szolgáltatáshoz kapcsolódó } \\
\text { szerződések kikényszeríthetősége, } \\
\text { a technológia létrehozásához és alkalmazásához } \\
\text { kapcsolódó tranzakciós költségek, } \\
\text { állam által nyújtott innovációs ösztönzők }\end{array}$ \\
\hline L4 & $\begin{array}{l}\text { Erőforrás-allokáció és } \\
\text { foglalkoztatás }\end{array}$ & $\begin{array}{l}\text { az innováció megvalósításához szükséges fizikai és } \\
\text { humán erőforrások elosztása, az újítás kockázatai }\end{array}$ \\
\hline
\end{tabular}

Williamson, 2000 és Czeglédi, 2005 alapján saját összeállítás 
A hierarchikusan felépített struktúra legfelső szintjén lényegében a northi informális intézmények helyezkednek el. A társadalom és az egyének újhoz való hozzáállását, innovációs hajlandóságát, illetve az új tudás létrehozásához szükséges képességét, az innovációs potenciált alapjaiban határozza meg a kultúra. A második szinten lévő intézményi környezet teremti meg az innovációs tevékenység formális feltételeit. Az innovációs folyamat jogi hátterét, illetve a tudásáramlás feltételrendszerét biztosító nemzeti innovációs rendszer, illetve a tulajdonjogok közül elsősorban a szellemi tulajdon védelme lényeges. North $(1990,140$.) szerint éppen a tulajdonjogok biztonsága volt az egyik olyan intézményi elem, amely az Angliában bekövetkező gyors gazdasági fellendülésnek, valamint az angol hegemóniának alakító tényezője volt. A harmadik, az irányítási formák szintjén, a kormányzat ,innovációhoz való hozzáállása” fontos, hiszen nemcsak ösztönzöleg, hanem korlátként is szolgálhat az újítás folyamatában. A tulajdonjogi védelem és a szerződések kikényszerítésének hiánya visszatarthatja az innovátorokat. A negyedik, erőforrás-allokációs szinten az újdonságok létrehozásához szükséges erőforrások, illetve kockázatok elosztása jelenik meg.

Acemoglu és szerzőtársai (2005) a hosszú távú gazdasági növekedést meghatározó intézményi tényezők esetében gazdasági és politikai intézmények között tesznek különbséget. A politikai intézmények a politikai hatalom társadalmon belüli megosztását determinálják, míg a gazdasági intézmények ösztönzőket és korlátokat is teremtenek a gazdasági szereplök számára, mely révén meghatározzák a gazdaság müködését. A politikai hatalom két típusa különíthető el. A kollektív cselekvés és az erőforrások birtoklása révén társadalmi csoportok által birtokolt de facto politikai hatalom nyomást gyakorolhat a kormányzási formát és a politikai berendezkedést meghatározó de jure politikai hatalomra, hogy számukra kedvező politikai és azokon keresztül gazdasági intézményeket alakítson ki. Az állam a politikai intézményeken keresztül képes befolyásolni a gazdasági szereplők viselkedését, tehát a politikai hatalom jelentős hatást gyakorol a gazdasági intézmények hatékonyságára.

Az erőforrás-elosztást determináló és lassan változó politikai intézmények befolyásolják tehát a gazdasági intézmények kialakulását, melyek két fő csoportját alkotó tulajdonjogi és szerződéses intézmények közvetlenül hatnak a gazdaság teljesítményére (Acemoglu et al., 2005). A tulajdonjog védelme az elit és a kormány által történő kisajátítás kockázatát redukálja, míg a szerződéses intézmények az egyenlő szereplők közötti tranzakciók lebonyolításához szükséges szerződések megkötésének hátterét biztosítják. A hatékony gazdasági intézmények garantálják a tulajdonjogok védelmét, miközben relatíve egyenlő hozzáférést biztosítanak az erőforrásokhoz a társadalom tagjai számára, mely azonban nem feltétlenül generál növekedést (Acemoglu et al., 2005).

A technológiai változás egyfajta sokkhatásként éri a gazdasági szereplőket, mely megváltoztatja az erőforrás-allokációt és az intézményi struktúrát is. Az új 
technológia bevezetését különböző érdekcsoportok megakadályozhatják, ily módon a gazdasági változások de facto politikai hatalomra gyakorolt hatása kulcstényező a haladás megvalósulásában. A schumpeteri „kreatív rombolás” során az új technológia kiszorítja a régit, mely révén lesznek politikai és gazdasági vesztesek is. A gazdasági vesztesek járadékukat és piaci pozíciójukat veszíthetik el az újdonság megjelenésével, míg a politikai vesztesek a hatalmat, mely által az intézmények alakításának privilégiumát is. A régi és új technológiák tulajdonosai között tehát érdekütközések alakulnak ki, így az érdekcsoportok, valamint az új technológia alkalmazását akadályozó, országonként eltérő korlátok szerepe lényeges a technológiai fejlődés realizálódásában, melyek közül Czeglédi Pál (2010) a tulajdonjogok biztonsága és az érdekcsoportok mellett, az informális intézmények és a tranzakciós költségek jelentőségét is hangsúlyozza. Az új technológia létrehozásának és átvételének is alapvető intézményi feltétele a tulajdonjogok biztonsága, mely az állam, illetve politikai elit által történő kisajátítás elleni védelmet jelenti elsősorban. Acemoglu és szerzőtársai (2005) országkeresztmetszeti regressziós számításai alátámasztják ennek jelentőségét, eszerint a kisajátítási kockázat elleni védelem, azaz a tulajdonjogi biztonság és a GDP pozitív irányú kapcsolatot mutat. A tulajdonjogok biztosítása nélkül nem motivált a szereplö, hogy befektessen egy új technológiába. A tulajdonjogok kikényszerítésében az állam szerepvállalása lényeges, a politikai hatalommal rendelkezőknek biztosítaniuk kell a magántulajdon biztonságát, és el kell kötelezniük magukat amellett, hogy ök sem sértik meg azokat.

Az intézmények különböző szempontok szerint csoportosíthatók tehát attól függően, mely tulajdonságukra helyezzük a hangsúlyt, és milyen kontextusban vizsgálódunk. A technológiai fejlődés és a gazdasági növekedés vonatkozásában elsősorban a formális és informális, valamint a gazdasági és politikai intézmények elkülönítése lényeges. Az intézményrendszer kialakulásában meghatározóak a társadalmi berendezkedés, a társadalom tagjai által vallott értékek, normák, magatartási minták. A formális szabályok biztosítják a gazdasági müködés feltételrendszerét. A hatalommegosztás és az érdekcsoportok nagymértékben befolyásolják azt, hogy egy adott gazdaságban milyen intézmények vannak.

\section{ÖSSZEGZÉS}

Nincs intézményi egyenrecept a technológiai fejlődéshez.

Az intézmények szerepe a technológiai haladás megvalósulásában kétségkívül releváns. Az intézményrendszer teremti meg az újító tevékenységhez szükséges ösztönzőket, melyek az új technológia létrehozását, alkalmazását és a terjedését egyaránt befolyásolják. Az országok között megfigyelhető jövedelmi és tech- 
nológiai fejlettségbeli eltérések a technológia terjedésének és az azt befolyásoló ösztönzőrendszereknek a különbözőségeire vezethetők vissza. A technológiai fejlődés szempontjából a politikai, gazdasági és jogi szabályokat, valamint a szerződéseket magában foglaló formális korlátok közül elsősorban a törvények és a tulajdonjogok lényegesek, míg az informális korlátozások mint a normák és a viselkedési szabályok kiegészítik és növelni tudják a formális szabályok hatékonyságát. A technológiai fejlődés elválaszthatatlan kísérőjelensége az újításhoz kapcsolódó bizonytalanság, melynek csökkentésében az intézmények fontos szerepet töltenek be. Ennél is fontosabb azonban az, hogy mi motiválja a gazdasági szereplőket arra, hogy kiszámíthatatlan kimenetelü kutatás-fejlesztési tevékenységet folytassanak, s mi garantálja, hogy az általuk létrehozott újdonság hasznait realizálni is tudják.

A jövedelmi, technológiai és intézményi összefüggéseket jól szemléltethetjük országok tanulmányozásán keresztül. Mancur Olson (1996) rámutat, hogy az országok közötti jövedelmi eltérések nem magyarázhatók csupán a humán és fizikai tőke különbözőségeivel, plauzibilis magyarázatot az országok között minőségben eltérő intézmények és gazdaságpolitika adhatnak. Acemoglu és szerzőtársai (2005) Dél- és Észak-Korea példáján illusztrálják, hogy azonos földrajzi, történelmi és kulturális háttérrel rendelkező gazdaságok esetében a fejlődési pálya eltérései döntően az intézményi berendezkedéssel magyarázhatóak. Európában is jelentősen hozzájárult az intézményi környezet az országok közötti jövedelemegyenlötlenségek kialakulásához. A közép- és kelet-európai országok lemaradása a II. világháborút követő politikai berendezkedésnek köszönhetóen kialakult intézményrendszerük sajátosságaival magyarázható.

A 18. század végén, Nagy-Britanniában kibontakozó ipari forradalom egy átfogó technológiai, gazdasági és társadalmi változást indított el, amely új irányba terelte a közgazdasági gondolkodást. Mokyr (2004) az ipari forradalmat vizsgálva arra a következtetésre jut, hogy a teljesen új, előzmények nélküli makrotalálmányok, amelyek lényegében determinálták az ipari forradalmat, valamint a meglévő dolgok tökéletesítésére, leegyszerüsítésére irányuló mikrotalálmányok komplementaritása adta az ipari forradalom elsöprő erejü gazdasági hatását, amely elindította a jövedelmek növekedését. Nem maguk a találmányok voltak fontosak, hanem a terjedésük, annak a társadalmi környezetnek a minősége, amelyben érvényesülhetett makrogazdasági hatásuk. Abban a korban a briteknek ugyanis nem volt olyan tudományos előnyük, mely magyarázta volna a technológiai előnyüket (Mokyr, 2004). Az első ipari forradalom vezető nagyhatalma, Nagy Britannia azonban fokozatosan elvesztette technikai fölényét. Napjainkban az innováció területén kiemelkedő teljesítményt a skandináv államok nyújtanak. Az Európai Unió 2018-as innovációs eredménytáblája alapján Svédország Európa vezető innovátor országa, melyet Dánia, Finnország, Hollandia és az Egyesült Királyság követ (Eurostat, 2018). Az innováci- 
ós teljesítmény mérései alapján Nyugat-Európa és a skandináv államok között egyre jobban éleződik a technológiai rés. Az empirikus tapasztalatok tehát azt mutatják, hogy a brittel élesen ellentétes központosított struktúra is hatékony a technológiai fejlődés számára, olyan egyedi eredmények valósulnak meg, melyek alapján a modell sikeressége nem kérdőjelezhető meg. A kvalitatív illusztrálás alapján tehát az is láthatóvá válik, hogy eltérő intézményi berendezkedésü országokban is lehet kimagasló innovációs teljesítményt elérni, azaz nincs intézményi egyenrecept a technológiai fejlődéshez.

\section{IRODALOM}

Acemoglu, D. - Johnson, S. - Robinson, J. (2005): Institutions as the Fundamental Cause of Longrun Growth. In: Aghion, Ph. - Durlauf, S. N. (eds.): Handbook of Economic Growth. Volume 1A, Ch. 6. Elsevier, 385-472. https://economics.mit.edu/files/4469

Czeglédi P. (2004): Humán tőke és intézmények az endogén növekedéselmélet korai modelljeiben. Competitio, 3, 2, 135-149. https://dea.lib.unideb.hu/dea/handle/2437/91181

Czeglédi P. (2005): A társadalmi elemzés szintjei a növekedéselméletben. In: Hámori B. - Czeglédi P. - Jankovics L. et al. (szerk.): Paradigm Shift-Information, Knowledge and Innovation in the New Economy. Conference Proceedings. (Competitio könyvek 4) Debrecen: 267-282. https://dea.lib.unideb.hu/dea/handle/2437/91350?locale-attribute=hu

Czeglédi P. (2010): A technológiai haladás intézményi korlátai: áttekintés. In: Kapás J. (szerk.): Technológiai fejlödés és intézmények. (Competitio könyvek 10) Debrecen: 39-58.

Eurostat (2018): European Innovation Scoreboard 2018. https://ec.europa.eu/docsroom/documents/32503

Hall, R. E. - Jones, Ch. I. (1999): Why Do Some Countries Produce So Much More Output Per Worker than Others. The Quarterly Journal of Economics, 114, 1, 83-116. https://web.stanford. edu/ chadj/HallJonesQJE.pdf

Kapás J. (2007): Hogyan fejlődik a vállalat? A fizikai és a társadalmi technológia kölcsönhatásos evolúciós folyamata. Közgazdasági Szemle, LIV., január, 49-66. http://web.unideb.hu/jkapas/ pdf $/$ Kap $\%$ C3\%A1s_hogyan\%20fej1\%C5\%91dik\%20a\%20v\%C3\%A1llalat.pdf

Mokyr, J. (2003): Thinking about Technology and Institutions. Macalester International, 13, $33-66$.

Mokyr, J. (2004): A gazdagság gépezete - technológiai kreativitás és gazdasági haladás. Budapest: Nemzeti Tankönyvkiadó, http://digitalcommons.macalester.edu/cgi/viewcontent.cgi?article $=1412 \&$ context $=$ macintl

Nelson, R. R. (2002): Bringing Institutions into Evolutionary Growth Theory. Journal of Evolutionary Economics, 12, 17-28. DOI: 10.1007/s00191-002-0108-x, https://www.researchgate. net/publication/24057938_Bringing_Institutions_into_Evolutionary_Growth_Theory

North, D. C. (1990): Institutions, Institutional Change, and Economic Performance. Cambridge: Cambridge University Press

Olson, M. (1996): Distinguished Lecture on Economics in Government. Big Bills Left on the Sidewalk: Why Some Nations are Rich, and Others Poor. The Journal of Economic Perspectives, 10, 2, 3-24. DOI: 10.1257/jep.10.2.3, https://www.aeaweb.org/articles?id=10.1257/ jep.10.2.3 
Pelikan, P. (2003): Bringing Institutions into Evolutionary Economics: Another View with Links to Changes Physical and Social Technologies. Journal of Evolutionary Economics, 13, 3, 237-258.

Solow, R. M. (1956): A Contribution to the Theory of Economic Growth. The Quarterly Journal of Economics, 70, 1, 65-94. http://piketty.pse.ens.fr/files/Solow1956.pdf

Williamson, Ó. E. (2000): The New Institutional Economics: Taking Stock, Looking Ahead. Journal of Economic Literature, XXXVIII., September, 595-613. DOI: 10.1257/jel.38.3.595, https:// www.researchgate.net/publication/4981429_The_New_Institutional_Economics_Take_Stock_ Looking_Ahead 